in two of our cases raises the question whether the sensitivity to mustine is really allergic. The latency and nature of the skin reaction and the results of patch testing, however, indicate that allergy is concerned, and the occurrence of contact urticaria and bronchial asthma in one case further supports the idea of an allergic mechanism. We think that it is important to investigate the effect of PUVA on other forms of allergic contact dermatitis as well as urticaria.

This work was supported by the Danish Cancer Society, the Norwegian Cancer Society, and the Swedish Cancer Society.

Request for reprints should be addressed to Dr Lars Molin.

1 Volden, G, and Eeg Larsen, T, Dermatologica, 1977, 156, 129.

2 Waldorf, D S, Haynes, H A, and van Scott, E J, Annals of Internal Medicine, 1967, 67, 282.

3 Grunnet, E, British fournal of Dermatology, 1976, 94, 101.

4 Molin, L, et al, Cutis, in press.

5 Frosch, F J, and Kligman, A M, Archives of Dermatological Research, 1978, 261,110 .

(Accepted 19fuly 1978)

Department of Dermatology, Rikshospitalet, Oslo, Norway

G VOLDEN, MD, senior registrar

Department of Dermatology, University Hospital, S-581 85 Linköping, Sweden

L MOLIN, MD, senior consultant

Department of Dermatology, Finsen Institute, DK-2100 Copenhagen, Denmark

K THOMSEN, MD, senior consultant

\section{Prolonged treatment of high-renin hypertension with a converting enzyme inhibitor}

The nonapeptide teprotide (SQ 20881) inhibits the enzyme responsible for converting angiotensin I to angiotensin II; this enzyme also degrades bradykinin. Teprotide depresses angiotensin II concentration and raises the bradykinin concentration in patients with essential hypertension ${ }^{1}$; and can lower blood pressure in hypertensive patients with high and normal plasma renin concentrations. ${ }^{2}$ Prolonged treatment of hypertension with a converting enzyme inhibitor has not been recorded, and we report its success.

\section{Case report}

A white woman aged 19 developed normotensive end-stage renal failure due to mesangiocapillary glomerulonephritis. Three months after cadaver renal transplantation she developed hypertension, which later became resistant to large doses of antihypertensive drugs. She developed recurrent left ventricular failure, severe headaches, and papilloedema; and her creatinine clearance fell from 20 to $8 \mathrm{ml}$ per minute. Her plasma renin concentration was appreciably raised on several occasions (20-34 ng angiotensin II generated/ml/minute), there was a $2: 1$ renin gradient across the transplant kidney, and angiography excluded renal artery stenosis.

Before starting teprotide her supine systolic blood pressure was 160-190 $\mathrm{mm} \mathrm{Hg}$ and phase $\mathrm{V}$ diastolic pressure was $120-140 \mathrm{~mm} \mathrm{Hg}$, despite daily total doses of oxprenolol, $640-960 \mathrm{mg}$; hydrallazine, $200 \mathrm{mg}$; bethanidine, $150 \mathrm{mg}$; phenoxybenzamine, $90 \mathrm{mg}$; and frusemide, $500 \mathrm{mg}$ (figure). Intermittent intravenous injections of teprotide caused appreciable reductions in blood pressure. One year after transplantation regular injections of this drug were given (initially intravenously, then intramuscularly and later subcutaneously) in doses of $0 \cdot 125-0 \cdot 25 \mathrm{mg} / \mathrm{kg}$ eight-hourly and her other antihypertensive drug treatment was reduced. There was a sustained reduction in blood pressure (figure); her headaches, left ventricular failure, and papilloedema resolved. She was taught to inject herself subcutaneously and to take her own blood pressure, and was discharged from hospital for the first time in six months. Clinical, haematological, and biochemical assessment showed no adverse effect of the drug. In particular, glomerular filtration rate, as indicated by frequent determinations of creatinine clearance and serum creatinine concentrations, did not fall further; and flushing and wheezing, which might have suggested an increased plasma bradykinin concentration, did not occur. Intramuscular and subcutaneous injections were well tolerated and free of pain.

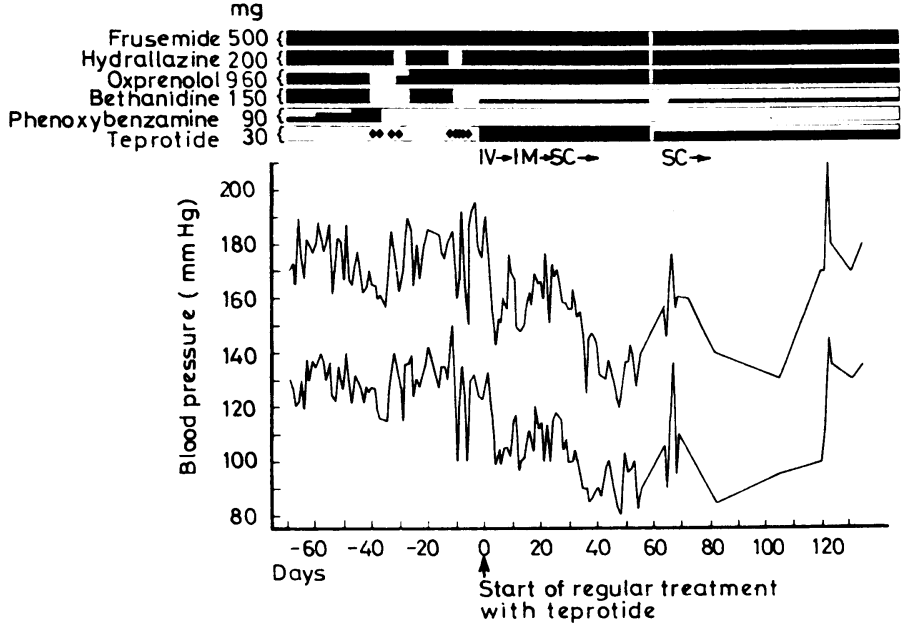

Effect of antihypertensive treatment on blood pressure. Daily means of supine systolic and diastolic blood pressure measurements (made at least four-hourly during hospital admission) are plotted.

= Total daily dose $(\mathrm{mg})$ of regularly given antihypertensive drugs.

= Initial intravenous injections of teprotide (SQ 20881) made to assess the dose response.

After four months' successful treatment with teprotide her renal function, which had been stable, deteriorated irreversibly. She developed uncontrollable hypertension and clinical evidence of salt and water retention, and peritoneal dialysis became necessary. The transplanted kidney was removed and showed features of severe chronic rejection.

\section{Comment}

Teprotide is inactive orally in man and until now has been used only intravenously. The longest reported duration of treatment is seven days. ${ }^{3}$ We controlled otherwise resistant high-renin hypertension for four months by using subcutaneous or intramuscular doses every eight hours in combination with previously ineffective antihypertensive drugs. Control was obtained without further deterioration in renal function despite the previously low and falling creatinine clearance.

Before the introduction of teprotide a transient hypotensive effect was observed when bethanidine or phenoxybenzamine was added to existing treatment; the use of the converting enzyme inhibitor in combination with other antihypertensives including a beta-blocker was not associated with tachyphylaxis. It seems likely that the success of treatment was due to inhibition of angiotensin II formation and possibly of bradykinin degradation, ${ }^{4}$ together with suppression of renin release by beta-blockade.

This case report shows the feasibility of long-term control of hypertension associated with high plasma renin activity using an injectable, orally inactive converting enzyme inhibitor. Short-term converting enzyme inhibition by an oral analogue (SQ 14225) has been described in normal subjects. ${ }^{5}$ The effects of SQ 14225 in hypertensive patients have yet to be evaluated.

We thank Miss L Rogers for her secretarial help.

1 Williams, G H, and Hollenberg, N K, New England fournal of Medicine, 1977, 297, 184

2 Case, D B, et al, New England fournal of Medicine, 1977, 296, 641.

3 Johnson, J G, et al, Clinical Science and Molecular Medicine, 1975, 48, 535.

4 VandenBurg, M J, Sharman, V L, and Marsh, F P, to be published.

${ }^{5}$ Ferguson, R K, et al, Lancet, 1977, 1, 775.

(Accepted 19 fuly 1978)

Department of Nephrology and Medical Unit, The London Hospital London E1

$M$ J VANDENBURG, MRCP, lecturer

V I SHARMAN, MRCP, senior registrar

F P MARSH, FRCP, consultant nephrologist

Squibb Institute for Medical Research, Princeton, New Jersey

E J RUCINSKA, MD, PHD, medical officer 